\title{
Socially Responsible Teaching and English Language Coursebooks: Focus on Ethnicity, Sex and Disability $^{1}$
}

\section{Toplumsal Sorumluluk Öğretimi ve İngilizce Ders Kitapları: Etnisite, Cinsiyet ve Engellilik}

\author{
Mustafa Bulut, Başkent Üniversitesi, Turkey, mbulut0443@gmail.com \\ Arda Arıkan, Akdeniz University, Turkey, ardaari@gmail.com
}

\begin{abstract}
The purpose of this study is to analyze the reading passages and related pictures published in English language coursebooks in terms of ethnicity, sex and disability by relating them to socially responsible teaching. A checklist formerly used by Cunningsworth (1995) was adapted and used for the purposes of this study. This checklist included the headings of nationalities, whether any kind of disability is included or not, types of disability, number of males and females and gender specific roles attached to males and females. A total of 240 reading passages were analyzed throughout the study and frequencies and percentages for each coursebook were calculated. Results indicate that the coursebooks analyzed generally lack sensitivity to differences based on nationalities, sexes and disability. Results also demonstrate that disability gets little or no place in the coursebooks studied. Also, it was found that females are not represented equally with males. With regards to ethnicity, native speakers of English appear in the coursebooks more than non-native speakers do.
\end{abstract}

\section{Keywords: Disability, Ethnicity, Sex, Nationality, Coursebook}

Özet: Bu çalışmanın amacı İngilizce ders kitaplarında yer alan okuma pasajları ve görsel araçların etnisite, cinsiyet ve engellilik bağlamında bir incelemesini ortaya çıkarmaktır. Cunningsworth (1995) tarafindan daha önce önerilmiş bulunan bir çetele bu çalışmanın veri toplama kısmında kullanılmıştır. Çetelede milliyetler, engelliliğin bulunma ya da bulunmama durumu, engellilik türü, erkek ve kadınların saylları ve onlara atfedilen meslek ve roller yer almaktadır. Toplam 240 okuma pasajı incelenmiş ve frekanslar ile yüzdelikler yoluyla sonuçlar ortaya konulmuştur. Çalışmanın sonuçlarına göre etnisite, cinsiyet ve engellilik ders kitaplarında hassasiyet gösterilen gerçeklerden değildir. Sonuçlara göre ders kitaplarında engellilik hemen hiç yer almazken kadınların rakamsal oranı erkeklerden daha azdır. Etnisite bağlamında ise anadili Ingilizce olan bireyler olmayanlara göre daha çok ilgi görmektedir.

Anahtar Sözcükler: Engellilik, Etnisite, Cinsiyet, Milliyet, Ders Kitabı

\section{Introduction}

Students and teachers face different kinds of large-scale problems such as those related to or stemming from our environment such as those about human rights, intercultural communication, socio-economic realities, and health. Similarly, like all courses and subject areas, English courses can be considered as grounds that help all participating agents read, comment on, speak about, and internalize these social problems, issues, and values. Dyer and Bushell (1996) claim that students should be encouraged to use their knowledge of English to clarify and express their values, to think and speak critically about world issues, and to judge and synthesize others' perspectives.

The term social responsibility (SR), which is primarily associated with business and governmental practices, is an ethical or ideological concept suggesting that every entity whether it is

\footnotetext{
1 This paper reports the Master's Degree thesis written by Mustafa Bulut under the supervision of Arda Arikan. It was accepted by Hacettepe University's Institute of Social Sciences, Ankara, Turkey, in 2008.
} 
Bulut, M. , Arıkan A. / Journal of Yasar University , 2015 , 10 (Special Issue) , 13-20

a village, town, state, corporation, organization, government or an individual has responsibility to society. Socially responsible teaching (SRT) is referred to as "issues of global significance" (Anderson, 1996). In recent years, there has been interest in global issues and global education and accordingly, a growing number of educators and researchers are currently discussing what the aims and goals of English language teaching should entail. Brown (1990), for example, phrases this in terms of the mission and goals of English language teaching:

What are we doing for the Earth? What are we doing to save it? What are the issues? And what on earth does this have to do with you as an ESL teacher? It has everything to do with you as an ESL teacher. Global, peace and environmental issues intrinsically affect every human being on earth. These issues provide content for your content-based humanized teaching of the 90's. We teachers have a mission, a mission of helping everyone in this world communicate with each other to prevent the global disaster ahead.

A similar view has also been stated by Maley (1992) who suggests that global issues are real issues and by making global issues a central core of EFL, problems would be, to some extent, resolved. SRT is based on peace education which respects learners' cultures, personalities and lives. It involves learners in shaping the lessons by allowing them to explore what is of interest and concern to them. Ghaith and Shaaban (1994) present ideas for incorporating peace education in language instruction with a focus on three aspects, namely, themes, skills, and methods. Themes for peace education include:

1. international conflicts (wars and trade disputes),

2. international cooperation (people, organizations and governments from various countries working together to work on environmental issues, developing new medicines from plants),

3. other countries and cultures (students can come to know them and appreciate their histories and virtues),

4. cross-cultural communication (students come to understand that people communicate in different ways and there are types and root-causes of violence which should be understood that violence does not need to be a part of their lives).

Social justice is an important aspect of SRT. According to McInerney (2004), the idea of social justice does not have a single or universally accepted meaning. Diverse views and orientations are embedded in discourses which are historically and culturally constituted and which reflect competing political endeavors. Not only is the very notion of social justice a contested one, but it seems to coexist with a range of ideas and expressions related with equality, fairness and human rights. Many writers are concerned with specific forms of injustice and oppression such as those arising from social classes, genders and racialized experiences of individuals, groups and those related with disability.

We face serious global problems such as hunger, racism, inequality, and terrorism while several writers challenge prevailing technical conceptions of teachers' work by struggling for reform in teacher education. Giroux (1985) makes a case for teachers as transformative intellectuals and Freire (1998) speaks of teachers as cultural workers. Some others assert that teaching for social justice should be the core of teachers' work, even if it means 'teaching against the grain'. It is also claimed that the most important goals of teacher education programs should be SR, social change and social justice (Freire 1994). In a similar vein, Nieto (2000) argues that equity needs to be brought to the centre of teacher education. According to (Yakovchuk 2004), one of the possible practical ways of teaching languages with an emphasis on peace education could be using global issues as the subject matter. This would gradually raise prospective teachers' awareness of the importance of global education and fits in well with current trends leading our practice in foreign language teaching methodology. Similarly, Cates (2000) claims that we cannot call our language teaching practices successful if our students, however fluent they are in their language learning, remain ignorant of world problems or refrain from using their communication skills to strengthen actions against 
Bulut, M. , Arıkan A. / Journal of Yasar University , 2015 , 10 (Special Issue) , 13-20

international crime, exploitation, oppression or environmental destruction. It is from this context that teaching SR in the language classroom seeks to pursue what is morally and ethically correct.

Research on gender representation as it appears in coursebooks published in Turkey shows that women are given secondary roles. Helvacioğlu's (1996) study of coursebooks revealed that women were portrayed as passive housewives. Similarly, Arikan (2005) found that women represented in no more than $30 \%$ of all the visual images given in English language coursebooks while they were shown doing "feminine" sports like aerobics and yoga. In terms of gender, even though the representation of women and men shows an equal balance, Similarly, Cunningsworth (1995) found in his study of coursebooks that famous men outnumber women in history as eighteen out of twenty characters are males on topics on famous people. Browne (1998) also found that housework and childcare are still portrayed predominantly as women's work. Despite the fact that we have some research available on gender representation in English language coursebooks, research on ethnicity is yet scarce especially in Turkey. This shortsighted view is often ascribed to Turkey's being a strong nation state which disregards ethnic plurality (Sendika.org 2014). In terms of disability, it can be said that the concept is rather new to the country as the government and municipalities have recently started working towards meeting the needs of this disadvantaged population in the last one or two decades. However, such research is available about visually impaired individuals especially in library and communication studies (Kazak 2002).

Cunningsworth (1995) further states that because gender differences are not the only area of possible discrimination, it's also illuminating to look at instructional materials to see if and how they represent people according to their ethnic origins, occupations, ages, social classes, and disabilities. Hence, our purpose in this study was to understand how people with disabilities, different ethnic origins, and sexes were portrayed in English language coursebooks. Specifically, we aimed to find answers to the following research questions:

1. Do disabled individuals get attention in the passages and the related pictures? (Disability)

2. Do people from different countries appear in the passages and pictures? (Ethnicity)

3. Are women and men represented equally and what professional and social positions are attributed to them? (Sex)

\section{Method}

In this study, a checklist formerly used by Cunningsworth (1995) was adapted to answer the above mentioned research questions. A checklist was prepared for each coursebook including the points that were the main focus of the study, namely, whether or not disability was included, individuals' nationalities, number and social roles attached to males and females. For each disability type, nationality, and social role, a specific code was prepared. The reading passages and the accompanying pictures in each coursebook were analyzed carefully by the researchers and whenever disability, nationality, and social role appeared, these were written down in the checklist. In order to determine the background information on the native speakers of English, the nationalities where English is spoken as native language were taken as the basis.

Data were represented in frequencies and percentages. The texts or illustrations causing ambiguity were found to be less than 5\% among all reading passages. Those ambiguous materials were excluded from the final analysis. In the selection of the coursebooks, the most popular coursebooks used in Turkey as well as in the world are selected for inclusion. The list of most popular coursebooks was attained through online research and by looking at similar studies in the field. The coursebooks analyzed in this study (with the number of the reading passages analyzed given in parentheses) were The New Headway (12), Enterprise 4 (12), Cutting Edge (10), Opportunities (12), Think Ahead to First Certificate (32), Hotline (12), Life Lines (14), Spotlight on English (24), New Bridge to Success (60), and Streetwise (50). The coursebooks were written by native-speakers of English except for New Bridge to Success and Spotlight on English both of which are written by Turkish writers and are used in Turkish schools as suggested by the Ministry of National Education. 
Bulut, M. , Arıkan A. / Journal of Yasar University , 2015 , 10 (Special Issue) , 13-20

\section{Findings}

\subsection{Disability}

Disability gets little attention in the coursebooks analyzed. Only 8 passages were found to deal with disability issues. Hence, only 3.3\% of the passages contain issues or characters related with disability. In sum, $96.7 \%$ of the passages and the related pictures portray characters that do not have any sort of with disability. For example, in The New Headway, disabled people are mentioned only in two passages out of twelve. In fact, there is no passage on a specific type of disability or everyday problems of the disabled. The second and the third passages are on a small girl and famous artists whose disabilities are mentioned in one or two sentences. A similar case is seen in Enterprise 4. A passage on disasters and accidents simply mentions a young girl who experiences emotional disturbance due to the immense effects of an earthquake in Los Angeles. The only success story, a passage which is completely written on the disabled ones, appears in Life Lines. Unlike other coursebooks which mention disabilities in one or two sentences, one single passage is about the success story of a well-known artist who has had an orthopedic impairment. The passage titled "I'm so lucky" portrays how Gloria Estefan had a terrible accident which broke her back and how she became successful again. However, it should also be noted that the title, "I'm so lucky" suggests that disability is a curse or an unwanted condition in that only those individuals who are lucky enough get away from being a person with a disability (Figure 1).
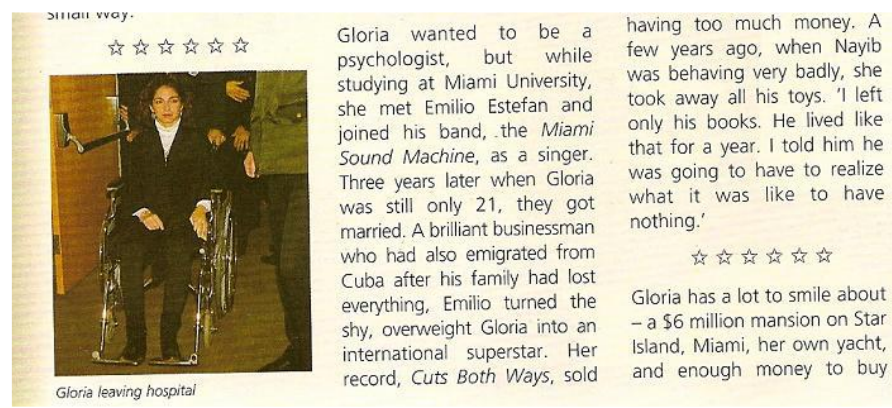

Gloria has a lot to smile about - a \$6 million mansion on Star Island, Miami, her own yacht, and enough money to buy

Figure 1. Representing disability

\subsection{Ethnicity}

Cunningsworth (1995) states that ethnicity is one of the main issues that should be given importance while evaluating coursebooks. It is important that people from different countries should appear in coursebooks simply because especially when English language is considered, English language speakers come from all sorts of life. Furthermore, despite knowing that reading passages should be accompanied by visual materials with a function and meaning rather being used for decorative purposes, the results of this study show that coursebooks mostly represent English, American and Turkish people without portraying them as whole persons. Furthermore, there are also imbalances in how particular nationalities are portrayed in specific coursebooks. For example, written by Turkish writers, Spotlight on English does not include any American characters. Results of this study show that British people $(24.6 \%)$ are given place more than the others in the coursebooks studied, followed by Americans from the US (11.6\%), and Turkish people (6.1\%). 
Bulut, M. , Arıkan A. / Journal of Yasar University , 2015 , 10 (Special Issue) , 13-20

Table 1. Nationalities

\begin{tabular}{|l|c|c|}
\hline Nationalities & f & \% \\
\hline British & 85 & 24.6 \\
\hline American (US) & 40 & 11.6 \\
\hline Turkish & 21 & 6.1 \\
\hline
\end{tabular}

As for the distribution of native and non-native speakers of English, the percentage of native speakers is $56.9 \%$ while the percentage for non-native speakers is $43.1 \%$. Although English is an international language and there are many countries where people learn and use English, these coursebooks do not represent most of these countries. It's known that more than 350 million people use English as their mother tongue. These people are from the US, Britain, Canada, New Zealand and Australia. However, when we look at the results, we see that their proportion is about $60 \%$, which does not represent the figures we see in our daily lives.

\subsection{Sex}

Results suggest that, the coursebooks analyzed are mostly male centered. The number of males represented is higher when compared to females. While there are 716 males in total $(60 \%)$, the number of females is only $483(40 \%)$.

Table 2. Males and their Professional Roles

\begin{tabular}{|l|c|c|}
\hline Professional roles & f & \% \\
\hline Artistic and literary figures & 90 & 18 \\
\hline Children & 72 & 14.4 \\
\hline Learners & 41 & 8.2 \\
\hline Sports people & 29 & 5.8 \\
\hline Leisure and travel & 29 & 5.8 \\
\hline
\end{tabular}

Males are portrayed as artistic and literary agents, children or teenagers, learners, people involved in sports, leisure activities, and travel. Males are mostly depicted and portrayed as successful writers, musicians, actors, and poets. Males are also associated with household and parental work, administrative and protective duties and as those involved in science, technology, health, business, teaching, and management. As these professions suggest, in terms of social roles, the coursebooks analyzed depict men in active roles who are in control. It's also noteworthy that they are, in general, not associated with any child-rearing or housework which are often associated with women.

Table 3. Distribution of Major Roles (Females)

\begin{tabular}{|l|c|c|}
\hline Professional roles & f & \% \\
\hline Children & 57 & 20.4 \\
\hline Learners & 47 & 16.8 \\
\hline Artistic and literary figures & 44 & 16.1 \\
\hline Household and parental duties & 41 & 14.6 \\
\hline Teaching and research & 16 & 5.7 \\
\hline
\end{tabular}

Females are mostly portrayed as children/teenagers, learners, artistic and literary people, housewives/mothers and teachers or researchers. They are usually beloved girlfriends, little children, 
Bulut, M. , Arıkan A. / Journal of Yasar University , 2015 , 10 (Special Issue) , 13-20

unhappy girls, caring mothers, students, writers, and hardworking housewives. Among them, the hardworking housewife is the most popular image (Figure 2)

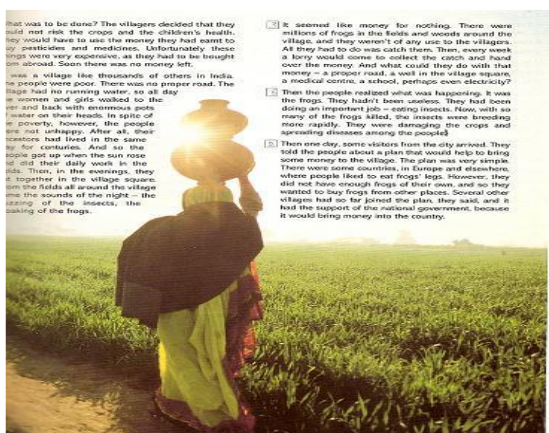

Fig 2. Representation of women in coursebooks (The people were poor, Life Lines)

In contrast to males, females are mostly portrayed in subordinate roles. Nevertheless, some passages and visuals project positive images of women with whom female students can identify themselves (Figures 3, 4 and 5).

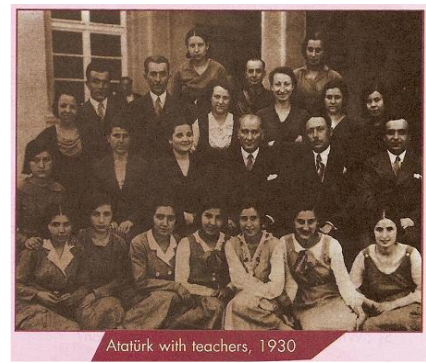

Fig 3. Images of women as teachers (Spotlight on English)

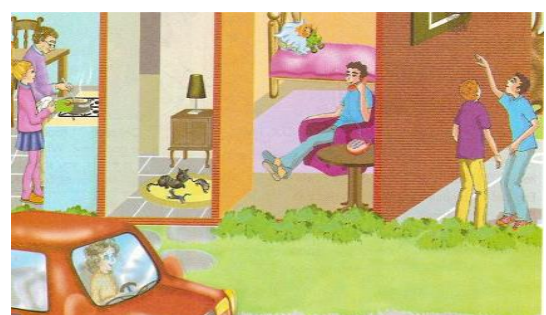

Figure 4. Men and women around the house (Spotlight on English)

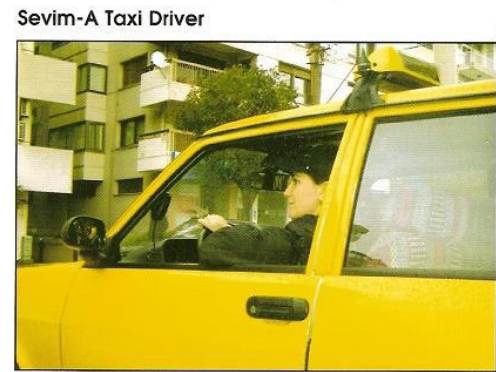

Figure 5. Women at men's work (New Bridge to Success) 
Bulut, M. , Arıkan A. / Journal of Yasar University , 2015 , 10 (Special Issue) , 13-20

\section{Conclusion}

This study found that disability and ethnicity are not allocated much space in the English language coursebooks studied as only $96.7 \%$ of the passages and the related pictures portray characters that do not have any sort of with disability. Similarly, although English is spoken by almost all nationalities and ethnicities, majority of characters in the coursebooks studied are American or British. In terms of gender, while there are 716 males in total (60\%), the number of females is only $483(40 \%)$, showing an unequal distribution. Furthermore, men are not associated with any child-rearing or housework which are often associated with women, showing the sexist tendencies of the coursebooks published. These results are in support of previous research studies which revealed similar results.

Classroom experience may have a profound effect on learners' views of themselves, their place in the world and most importantly their role as global citizens. Students who follow these coursebooks develop their own ideas about the world around them, especially the world beyond their immediate surroundings. As such, the content and values in coursebooks seem to be important as vehicles or transmitters of numerous knowledge pieces and sets of values.

SRT provides a venue for teachers and students to see the world in different perspectives and be able to examine and reflect upon how this diversity strengthens or disintegrates the social fiber that binds us. As we develop our linguistic and social competencies, we are encouraged to cultivate in ourselves a sense of respect, tolerance and sensitivity towards problems associated with race, gender, disability, environmental and social problems.

SR language teaching necessitates integration of social issues/values, global concerns and peace education into instructional materials and especially the coursebooks in order to teach what is morally and ethically correct. By this way, students will be encouraged to form a sense of respect, tolerance and sensitivity to differences among nationalities and ethnic groups, sexes, genders, disabilities, and social classes. In a way, we will try to better prepare them to be citizens of our world (Cates 2000).

There are some limitations to this study. As there were numerous ELT coursebooks available, it was quiet difficult to choose the most suitable samples for the study. To overcome this problem, the coursebooks used in Turkey and all around the world were chosen randomly. The second limitation of the study was that although the researchers had made every effort to analyze the reading passages and the accompanying pictures in detail, it is possible that some details may not have been noticed. 
Bulut, M. , Arıkan A. / Journal of Yasar University , 2015 , 10 (Special Issue) , 13-20

\section{REFERENCES}

Anderson, Gregory G. 1996. "Global issues in the university ESL classroom." The Language Teacher Online, no page.

Arikan, Arda. 2005. "Age, gender and social class in ELT coursebooks: A critical study." Hacettepe University Journal of Education. 28: 29-39.

Brown, H. Douglas. 1990. "On track to century 21." Plenary talk at the 24th annual convention of TESOL (Teachers of English to Speakers of Other Languages), San Francisco, USA.

Browne, Ken. 1998. An introduction to sociology. Cambridge: Polity Press.

Cates, Kip. 2000. "Entry for 'global education"', In Byram, M. (Ed.), Routledge Encyclopedia of Language Teaching and Learning. London: Routledge, 241-243.

Cunningsworth, Alan. 1995. Choosing your coursebook. Oxford: Heinemann.

Dyer, Brenda \& Bushell, Brenda. 1996. "World issues or a global perspective?" The Language Teacher, 20(11): 10-16.

Freire, Paulo. 1994. Pedagogy of hope: Reliving pedagogy of the oppressed. New York: Continuum.

Freire, Paulo. 1998. Teachers as cultural workers. Colorado: Westview Press.

Ghaith, Ghazi \& Shaaban, Kassim. 1994. "Peace education in the ESL classroom." TESL Reporter, 27(2): 55-62.

Giroux, Henry. 1985. “Teachers as transformative intellectuals.” Social Education, 49(5): 376-379.

Helvacıoğlu, Firdevs. 1996. Ders kitaplarında cinsiyetçilik 1928-1995. Kaynak Yayınları.

Kazak, Meliha. 2002. "Görme engellilere yönelik kütüphanecilik hizmetlerinde Türkiye'deki son gelişmeler: Gazi Üniversitesi Merkez Kütüphanesi görme engelliler bölümü örneği.” Türk Kütüphaneciliği , 22(2): 216-221.

Maley, Alan. 1992. "Global issues in ELT.” Practical English Teaching, 13(2): 73.

McInerney, Peter. 2004. "Mapping the literature: Social justice and education." Retrieved August 20, 2004, from www.ehlt.flinders.edu.au/education/sjrc/docs/Mapping_the_literature1.doc

Nieto, Sonia. 2000. "Placing equity front and centre: Some thoughts on transforming teacher education for a new century." Journal of Teacher Education, 51(3): 180-187.

Sendika.org. 2014, February 15. 5. Demokratik Eğitim Kurultayı: 'Özgürleşme yolunda'. Accessed August 7, $2004 \quad$ http://www.sendika.org/2014/02/5-demokratik-egitim-kurultayiozgurlesme-yolunda/

Yakovchuk, Nadezhda. 2004. "Global issues and global values in foreign language education." Accessed August 8, 2004, http://www.elted.net/issues/volume-8/yako-volume8.pdf 